\title{
Non-Compliance With Study Device
}

National Cancer Institute

\section{Source}

National Cancer Institute. Non-Compliance With Study Device. NCI Thesaurus. Code C139241.

An indication that a subject has not agreed with, or followed the instructions related to, the study device. 